\title{
Professional activity of stomatherapists graduated from the Federal University of Minas Gerais
}

\section{Atuação profissional dos estomaterapeutas egressos da Universidade Federal de Minas Gerais}

\section{Actuación profesional de los estomaterapeutas egresados de la Universidad Federal de Minas Gerais}

\author{
Thiago Gomes Gontijo ${ }^{1 *}$, Eline Lima Borges², Aidê Ferreira Ferraz², José Ferreira Pires Júnior², 3 , \\ Josimare Aparecida Otoni Spira²
}

ORCID IDS

Gontijo TG (D) https://orcid.org/0000-0002-7582-275X Borges EL (iD https://orcid.org/0000-0002-0623-5308 Ferraz AF (D) https://orcid.org/0000-0002-0610-3946 Pires Júnior JF (D) https://orcid.org/0000-0002-6019-0198 Spira JAO (D) https://orcid.org/0000-0002-6577-0394
HOW TO CITE

Gontijo TG; Borges EL; Ferraz AF; Pires Júnior JF; Spira JAO (2019). Professional activity of stomatherapists graduated from the Federal University of Minas Gerais. ESTIMA, Braz. J. Enterostomal Ther., 17: e1419. https://doi.org/10.30886/estima.v17.686_IN

\begin{abstract}
Objectives: This study aimed to identify the area of professional activity, characterize the trajectory and clinical practice in the area of stomatherapy, and identify further training as a specialist. Method: A descriptive study with a quantitative approach was conducted by applying an online questionnaire to graduates of the specialization course in Stomatherapy of the Federal University of Minas Gerais, which began in 2007, totaling 97 by 2015. The convenience sample was composed of 84 specialists who agreed to answer the questionnaire considering the study variables. Results: Most of the graduates were female (86\%), aged between 31 and 40 years (68\%), residents (58\%) and working (59.6\%) in Belo Horizonte. They remain active in their specialty area (70\%), with predominance of stoma and wound care (31\%), in care activities (29.3\%), in the hospital area (27.3\%) and in the health public sector (38\%). The pursuit of specialization was predominantly motivated by interest in technical-scientific development (48.5\%) and (69\%) of the graduates continues capacitating after specialization. Conclusion: Stomatherapy is expanding in the national market, requiring the continuation of national research for a broader view of the specialty.
\end{abstract}

DESCRIPTORS: Professional practice area; Nursing; Nursing specialties; Stomatherapy.

1.Centro Universitário Estácio de Belo Horizonte - Departamento de Saúde - Belo Horizonte/MG - Brazil.

2.Universidade Federal de Minas Gerais - Escola de Enfermagem - Programa de Pós-graduação em Enfermagem, Belo Horizonte/MG - Brazil.

3.Instituto Mário Penna - Hospital Luxemburgo - Serviço de Estomaterapia, Belo Horizonte/MG - Brazil.

Correspondence author: thiago.gontijo15@gmail.com

Received: Dec. 26, 2018 | Accepted: Aug. 28, 2019 


\section{RESUMO}

Objetivos: Este estudo teve como objetivos identificar a área de atuação profissional, caracterizar a trajetória e a prática clínica na área da estomaterapia e identificar posteriores capacitações como especialistas. Método: Estudo descritivo com abordagem quantitativa realizado por meio da aplicação de questionário online aos egressos do curso de especialização em Estomaterapia da Universidade Federal de Minas Gerais, iniciado no ano de 2007, totalizando 97 egressos até 2015. A amostra por conveniência foi composta pelos 84 especialistas que concordaram em responder o questionário contemplando as variáveis do estudo. Resultados: Os egressos eram em sua maioria do sexo feminino (86\%), com idade entre 31 e 40 anos (68\%), residentes (58\%) e atuantes (59,6\%) em Belo Horizonte. Mantêm-se atuantes em sua área de especialidade (70\%), com predominância dos cuidados com estomias e feridas (31\%), em atividades assistenciais (29,3\%), na área hospitalar (27,3\%) e no setor público de saúde (38\%). A busca pela especialização foi motivada predominantemente pelo interesse no desenvolvimento técnico-científico (48,5\%) e (69\%) dos egressos continua se capacitando após a especialização. Conclusão: A estomaterapia encontra-se em expansão no mercado nacional, sendo necessária a continuidade de pesquisas de âmbito nacional para uma visão mais abrangente da especialidade.

DESCRITORES: Área de atuação profissional; Enfermagem; Especialidades de enfermagem; Estomaterapia.

\section{RESUMEN}

Objetivos: Este estudio pretendió identificar el área de actuación, caracterizar la trayectoria y la práctica clínica en el área de la estomaterapia e identificar subsiguientes capacitaciones como experto. Método: Estudio descriptivo con enfoque cuantitativo llevado a cabo mediante la aplicación de un cuestionario en línea a los egresados del Curso de Especialización en Estomaterapia de la Universidad Federal de Minas Gerais, iniciado en el año 2007, totalizando 97 hastas el año 2015. La muestra de coveniencia consistió em 84 expertos que aceptaron responder el cuestionario considerando las variables del estúdio. Resultados: La mayoría de los egresados eran mujeres (86\%), con una edad comprendida entre los 31 y los 40 años (68\%), residentes (58\%) y actuantes (59,6\%) en Belo Horizonte. Se mantienen actuantes en el área de especialidad (70\%), con predominio de la atención a las estomías y las heridas (31\%), en actividades de asistencia (29,3\%), en el área hospitalaria (27,3\%) y en el sector público de salud (38\%). La búsqueda de especialización estuvo motivada, predominantemente, por el interés en el desarrollo técnico-científico (48,5\%) y (69\%) de los egresados siguen siendo entrenados post-especialización. Conclusión: Se concluye que la estomaterapia se está expandiendo en el mercado brasileño, lo que requiere la continuidad de investigaciones nacionales para una visión más amplia de esta especialidad.

DESCRIPTORES: Ubicación de la práctica profesional; Enfermería; Especialidades de enfermería; Estomaterapia.

\section{INTRODUCTION}

The specialization courses in Nursing propose and provide to professionals updating and specialization of specific knowledge in the execution of care, administrative, managerial, teaching, research, and integration activities. The nurse needs to improve the practice of care to the client, family, and community, in any context, that meets not only the expectations of the health system but especially the real needs of the population ${ }^{1}$.

The nurse specialist in stomatherapy or stomatherapist is the professional who has the technical knowledge, specific qualification and skills to assist people with stomas, acute and chronic wounds, fistulas and anal and urinary incontinence, in preventive actions, therapy and rehabilitation in search of a better quality of life $\mathrm{e}^{2,3}$.

The process of formation of the stomatherapist, according to the Brazilian Association of Stomatherapy (SOBEST), requires the nurse to complete a specialization course in Stomatherapy Nursing, which has full coverage in the areas of specialty (stomas, wounds, fistulas and anal and urinary incontinence), and is recognized by national education agencies, by Sobest and accredited in World Council of Enterostomal Therapists (WCET) ${ }^{2}$.

Stomatherapy gained worldwide prominence in 1978, with the creation of an international representative body, the WCET, which aims to promote the identity of stomatherapy, favor the sharing of information among professionals, contribute to the technical and scientific development of the specialty, the standardization of actions aimed at a better performance of stomatherapy and, consequently, the quality of care provided to the person with stoma, as well as the person with wounds and incontinence ${ }^{3}$.

In Brazil, stomatherapy formally began in 1990 with the introduction of the specialization course in Stomatherapy Nursing at the Nursing School of the University of São Paulo ${ }^{4}$.

Another considerable milestone in the history of Brazilian stomatherapy was the foundation of the 
Brazilian Society of Stomatherapy (Sobest) in December 1992. In 1997, it was renamed as the Brazilian Association of Stomatherapy: stomas, wounds, and incontinence, because it is nonprofit. In 2003, SOBEST created the journal Estima, an official tool for stomatherapy diffusion which deals with scientific and current knowledge of the specialty fields ${ }^{4}$.

The Nursing School of the Federal University of Minas Gerais (EEUFMG) was a pioneer in the state of Minas Gerais when it created the first specialization course in stomatherapy. Since its first classes, the course has been registered in SOBEST and WCET.

The course began at the EEUFMG in 2007, with an average of 13 slots offered per year. The objectives of the course are to provide the nurse with the basis to deepen specific knowledge and develop his technical, pedagogical, managerial, and investigative competence. It is a course with an innovative pedagogical proposal that aims to meet the diversity of demands of the job market in the area, corresponding to advances in nursing as a science and the various health needs of the population ${ }^{2}$.

When considering the historical milestones of the UFMG course and its theoretical and practical scope for professionals after the graduation of eight classes, it was necessary to identify the professional activities of these specialists as agents of multiplication of knowledge and social transformation. In order to continue the changes, it is essential to identify the reality of the graduates of the specialization course in Stomatherapy Nursing; for this reason, the interest in studying this topic emerged.

The results of this study will contribute to the dimensioning and mapping of the insertion of stomatherapists in the job market, the basis to review the curriculum of specialization courses, as well as identifying gaps in knowledge that will favor further and complementary studies. They may also enable the assessment of opportunities for the insertion of stomatherapists in the practice of the specialty.

\section{OBJECTIVES}

To identify the professional area of stomatherapists graduated from UFMG, to characterize their trajectory and clinical practice with the specific area of work in stomatherapy and to identify further qualification as specialists in the field.

\section{METHODS}

This is a descriptive study with a quantitative approach covering participants from the Brazilian states of Minas Gerais, Bahia, Espírito Santo, São Paulo, and Mato Grosso do Sul, who graduated from the specialization course in Stomatherapy at EEUFMG.

In the period from 2007 to 2015, the UFMG course graduated eight classes, totaling 97 specialists. To compose the sample, the graduates were invited to participate in the study by a letter sent via electronic mail. After one month, the team received the acceptance of 84 specialists (86.5\%) that were part of the sample, for convenience.

The data collection occurred from March to April 2017 and required the preparation of a questionnaire, through the application Google Forms, composed of 15 questions that included sociodemographic variables (name, age, gender, city in where they live, city in where they work, year of completion of the undergraduate course and year of completion of the specialization course in Stomatherapy) and professional profile of the specialists (areas of work after concluding the graduate course).

Initially, the participants received a link via e-mail to access and complete the questionnaire. After 15 days, the link was re-sent, also via e-mail, to the participants who had not yet answered the questionnaire.

The development of the research respected the ethical precepts established by Resolution No. 466, of 12 December 2012. The Research Ethics Committee approved the study of UFMG (CAAE 64685417.7.0000.5149) under-report number 2,022,019. The graduates accepted to participate in the study after clarifications and explanation of the research development signed the Informed Consent Form (ICF) and sent it digitally via e-mail. They were guaranteed anonymity and no financial burden.

The obtained data were typed in Microsoft Office Excel spreadsheets, version 2007. Subsequently, the charts were submitted to descriptive analysis, and the results were discussed in the light of literature.

\section{RESULTS}

The sample consisted of 84 graduates of the specialization course in Stomatherapy of the EEUFMG, 
which corresponded to $86.5 \%$ of the total number of graduates in the period from 2007 to 2015 . The presentation of the sociodemographic variables of this sample is shown in Table 1.

Females prevailed in gender characterization (85.7\%). Most of the participants were aged between 31 and 40 (67.8\%), followed by 41 to 50 (13.1\%), and 20 to 30 years old (8.3\%), with a minimum age of 27 , maximum age of 66 and an average age of 38.4 .

Fifty-nine (58.3\%) of the graduates live in Belo Horizonte/MG, 22 (26.2\%) in Minas Gerais' inland cities, 8 (9.5\%) in Contagem/MG and 1 (1.2\%) in Betim/MG. It was identified that 4 (4.7\%) graduates live in other states: 1 (1.2\%) in Ponta Porã/MS, 1 (1.2\%) in São Paulo/SP, 1 (1.2\%) in Teixeira de Freitas/BA and 1 (1.2\%) in Vitória/ES.

As for the city they work in, 50 graduates (59.5\%) work in Belo Horizonte, 19 (22.6\%) in Minas Gerais' inland cities, 4 (4.7\%) in Contagem/MG, 3 (3.6\%) in Betim/MG, 4 (4.7\%) in other states (Bahia, Espírito Santo, Mato Grosso and São Paulo) and 2 (2.4\%) graduates work in more than one state. Currently, 2 (2.3\%) graduates are unemployed.

Regarding the year of completion of the undergraduate course, there were 36 graduates (42.8\%) between 2006 and 2010; and 24 (28.5\%) between 2001 and 2005.

Among the 84 graduates of the stomatherapy course who participated in this research, the predominance of the year of completion of the course was 19 (22.6\%) graduates in 2015, followed by 12 (14.3\%) in 2009, 12 (14.3\%) in 2014, $11(13.1 \%)$ in 2012, 10 (11.9\%) in 2010, 7 (8.3\%) in 2013, 5 (6.0\%) in 2008, 8 (9.5\%) in 2007 and 8 (9.5\%) in 2011.

Among the 84 participants in the study, 73 (86.9\%) work as nurses, and 11 (13.1\%) did not. Regarding the performance in the area of stomatherapy, $59(70.2 \%)$ nurses work in it and $25(29.8 \%)$ are not working in the area in question.

Concerning the specialty area of the active stomatherapist, Table 2 shows that 26 (31\%) work with stomas and wounds; 18 (21.5\%) only with wounds; 8 (9.5\%) with stomas, wounds and incontinence; 4 (4.7\%) with stomas and incontinence; and $3(3.5 \%)$ only with stomas. No participant showed to work only with incontinence and wounds and incontinence individually.

Among the activities related to stomatherapy, 59 (29.3\%) professionals chose the healthcare area, followed by self-employed care with $33(16.4 \%)$, education with 23 (11.4\%), assistance with 19 (9.4\%), consulting with 17 (8.5\%), management/administration and research, both with 13 (6.5\%), sales with 11 (5.5\%), 3 (1.5\%) participants selected "other activities", and $10(5 \%)$ never worked in any of the previously described activities. The question regarding these data is related to whether the professional practices or has already practiced some of these activities, with the possibility of choosing more than one response option.

Table 1. Sociodemographic profile of the participants.

\begin{tabular}{|c|c|c|}
\hline Variables & Categories & $\mathrm{N}^{\circ}(\%)$ \\
\hline \multirow{2}{*}{ Gender } & Female & $72(85.7)$ \\
\hline & Male & $12(14.3)$ \\
\hline \multirow{5}{*}{ Age (years) } & $20-30$ & $07(8.3)$ \\
\hline & $31-40$ & $57(67.8)$ \\
\hline & $41-50$ & $11(13.1)$ \\
\hline & $51-60$ & $06(7.1)$ \\
\hline & $61-70$ & $03(3.6)$ \\
\hline \multirow{8}{*}{ City they live in } & Belo Horizonte/MG & $49(58.3)$ \\
\hline & Betim/MG & $01(1.2)$ \\
\hline & Contagem/MG & $08(9.5)$ \\
\hline & Ponta Porã/MS & $01(1.2)$ \\
\hline & São Paulo/SP & $01(1.2)$ \\
\hline & Teixeira de Freitas/BA & $01(1.2)$ \\
\hline & Vitória/ES & $01(1.2)$ \\
\hline & MG's inland cities & $22(26.2)$ \\
\hline \multirow{10}{*}{ City they work in } & Belo Horizonte/MG & $50(59.5)$ \\
\hline & Betim/MG & $03(3.6)$ \\
\hline & Contagem/MG & $04(4.7)$ \\
\hline & Ponta Porã/MS & $01(1.2)$ \\
\hline & São Paulo/SP & $01(1.2)$ \\
\hline & Teixeira de Freitas/BA & $01(1.2)$ \\
\hline & Vitória/ES & $01(1.2)$ \\
\hline & MG's inland cities & $19(22.6)$ \\
\hline & Multiple states & $02(2.4)$ \\
\hline & Unemployed & $02(2.4)$ \\
\hline \multirow{5}{*}{$\begin{array}{l}\text { Year of completion of the } \\
\text { undergraduate course }\end{array}$} & 1978 to 1990 & $07(8.3)$ \\
\hline & 1991 to 2000 & $07(8.3)$ \\
\hline & 2001 to 2005 & $24(28.6)$ \\
\hline & 2006 to 2010 & $36(42.8)$ \\
\hline & 2011 to 2014 & $10(11.9)$ \\
\hline \multirow{9}{*}{$\begin{array}{l}\text { Year of completion of the } \\
\text { specialization course in } \\
\text { Stomatherapy }\end{array}$} & 2007 & $04(4.7)$ \\
\hline & 2008 & $05(6.0)$ \\
\hline & 2009 & $12(14.3)$ \\
\hline & 2010 & $10(11.9)$ \\
\hline & 2011 & $04(4.7)$ \\
\hline & 2012 & $11(13.1)$ \\
\hline & 2013 & $07(8.3)$ \\
\hline & 2014 & $12(14.3)$ \\
\hline & 2015 & $19(22.6)$ \\
\hline
\end{tabular}

Source: Research data, 2017 
Table 2. Professional profile of the participants.

\begin{tabular}{|c|c|c|}
\hline Variables & Categories & $\mathrm{N}^{\circ}(\%)$ \\
\hline \multirow{2}{*}{$\begin{array}{l}\text { Working as a nurse } \\
(n=84)\end{array}$} & Yes & $73(86.9)$ \\
\hline & $\mathrm{No}$ & $11(13.1)$ \\
\hline \multirow{2}{*}{$\begin{array}{l}\text { Working in } \\
\text { stomatherapy } \\
(\mathrm{n}=84)\end{array}$} & $\begin{array}{c}\text { Active } \\
\text { stomatherapists }\end{array}$ & $59(70.2)$ \\
\hline & $\begin{array}{l}\text { Nonactive in } \\
\text { stomatherapy }\end{array}$ & $25(29.8)$ \\
\hline \multirow{8}{*}{$\begin{array}{l}\text { Specialty area of the } \\
\text { active stomatherapist } \\
(n=84)\end{array}$} & Stomas & $3(3.5)$ \\
\hline & Wounds & $18(21.5)$ \\
\hline & Incontinences & $0(0.0)$ \\
\hline & Stomas and wounds & $26(31.0)$ \\
\hline & $\begin{array}{l}\text { Stomas and } \\
\text { incontinences }\end{array}$ & $4(4.7)$ \\
\hline & Wounds and incontinences & $0(0.0)$ \\
\hline & $\begin{array}{l}\text { Stomas, wounds, and } \\
\text { incontinences }\end{array}$ & $8(9.5)$ \\
\hline & Nonactive & $25(29.8)$ \\
\hline \multirow{10}{*}{$\begin{array}{l}{ }^{\dagger} \text { Activities related to } \\
\text { stomatherapy } \\
(n=201)\end{array}$} & Assistance & $19(9.4)$ \\
\hline & Care & $59(29.3)$ \\
\hline & Self-employed & $33(16.4)$ \\
\hline & Consulting & $17(8.5)$ \\
\hline & Education & $23(11.4)$ \\
\hline & $\begin{array}{l}\text { Management and } \\
\text { administration }\end{array}$ & $13(6.5)$ \\
\hline & Research & $13(6.5)$ \\
\hline & Sales & $11(5.5)$ \\
\hline & Other & $3(1.5)$ \\
\hline & Never worked & $10(5.0)$ \\
\hline \multirow{10}{*}{$\begin{array}{l}\text { Practice area/sector } \\
(n=190)\end{array}$} & Ambulatory & $25(13.2)$ \\
\hline & Home care & $42(22.2)$ \\
\hline & Private clinic & $9(4.7)$ \\
\hline & Hospital & $52(27.3)$ \\
\hline & Industry & $15(7.8)$ \\
\hline & $\begin{array}{l}\text { Primary health care } \\
\text { (ESF - UBS) }\end{array}$ & $20(10.5)$ \\
\hline & Universities/faculties & $13(6.8)$ \\
\hline & Other & $4(2.2)$ \\
\hline & Never worked & $10(5.3)$ \\
\hline & Ambulatory & $9(17.0)$ \\
\hline \multirow{4}{*}{$\begin{array}{l}{ }^{\dagger} \text { Practice area/sector } \\
\text { (hospital) }(n=52)\end{array}$} & Practice in all sectors & $27(52.0)$ \\
\hline & Intensive therapy & $3(6.0)$ \\
\hline & Inpatient unit & $13(25.0)$ \\
\hline & Comercial & $10(67.0)$ \\
\hline \multirow{3}{*}{$\begin{array}{l}\text { 'Practice area/sector } \\
\text { (industry) } \\
(n=15)\end{array}$} & Assistance programs & $2(13.0)$ \\
\hline & $\begin{array}{l}\text { Research and } \\
\text { development }\end{array}$ & $0(0.0)$ \\
\hline & Scientific & $3(20.0)$ \\
\hline
\end{tabular}

....continue
Table 2. Continuation...

\begin{tabular}{|c|c|c|}
\hline Variables & Categories & $\mathrm{N}^{\circ}(\%)$ \\
\hline \multirow{4}{*}{$\begin{array}{l}\text { Types of service } \\
(n=84)\end{array}$} & Private & $24(28.6)$ \\
\hline & Private and public & $18(21.4)$ \\
\hline & Public & $32(38.1)$ \\
\hline & Never worked & $10(11.9)$ \\
\hline \multirow{2}{*}{$\begin{array}{l}\text { Qualification after } \\
\text { stomatherapy course } \\
\text { completion } \\
(\mathrm{n}=84)\end{array}$} & Yes & $58(69.0)$ \\
\hline & No & $26(31.0)$ \\
\hline \multirow{9}{*}{$\begin{array}{l}\text { †Types of Qualification } \\
(n=179)\end{array}$} & Courses & $31(17.3)$ \\
\hline & Doctorate & $1(0.7)$ \\
\hline & Master's degree & $9(5.0)$ \\
\hline & International conference & $13(7.2)$ \\
\hline & National conference & $31(17.3)$ \\
\hline & Workshops & $38(21.4)$ \\
\hline & Symposia & $30(16.7)$ \\
\hline & Scientific meetings & $23(12.8)$ \\
\hline & Other & $3(1.6)$ \\
\hline \multirow{5}{*}{$\begin{array}{l}\text { 'Motivation to study } \\
\text { stomatherapy } \\
(n=140)\end{array}$} & Career advancement & $25(18.0)$ \\
\hline & Salary increase & $14(10.0)$ \\
\hline & $\begin{array}{l}\text { Scientific technical } \\
\text { knowledge }\end{array}$ & $68(48.5)$ \\
\hline & $\begin{array}{l}\text { Activities with patient } \\
\text { and family }\end{array}$ & $29(20.7)$ \\
\hline & Other & $4(2.8)$ \\
\hline
\end{tabular}

${ }^{\dagger} n \neq 8$ 8. Source: Research data, 2017.

Hospitals represent 52 (27.3\%) of the area of activity of the graduates of the Stomatherapy course, where 27 (52\%) practice in all sectors, $13(25 \%)$ in the inpatient unit, 9 (17\%) in the ambulatory and $3(6 \%)$ in the intensive care unit. Subsequent to the hospital area, there are $42(22.2 \%)$ in-home care, 25 (13.2\%) in the ambulatory, 20 (10.5\%) in primary healthcare, 15 (7.8\%) in industry, 13 (6.8\%) in universities/faculties and $9(4.7 \%)$ in private clinics. Of the $15(7.8 \%)$ operating in the industry, $10(67 \%)$ are in the commercial sector, 3 (20\%) in scientific research and development and 2 (13\%) in welfare programs. The question regarding these data is related to whether the professional works or has already worked in some of these areas, with the possibility of choosing more than one response option.

Thirty-two (38.1\%) graduated stomatherapists work or have worked in the public service, $24(28.6 \%)$ in the private service, 18 (21.4\%) in both, and 10 (11.9\%) stomatherapists have never worked.

Of the 84 participants, 58 (69\%) invested in professional qualification after specialization, and 26 
(31\%) did not. Among those who continued their qualification, 38 (21.4\%) attended in workshops, 31 (17.3\%) in national courses and congresses, 30 (16.7\%) in symposia, 23 (12.8\%) in scientific meetings, 13 (7.2\%) in international congresses, $9(5 \%)$ graduated from master's degree, 3 (1.6\%) did other activities and 1 $(0.6 \%)$ graduated from doctorate. The question regarding these data is related to whether the professional works or has already worked in some of these activities, with the possibility of choosing more than one response option.

The graduates were questioned as to the motivation to attend the Stomatherapy course and 68 (48.5\%) answered by their technical-scientific knowledge, 29 $(20.7 \%)$ as an opportunity to develop activities with patients and families, 25 (18\%) for career advancement, $14(10 \%)$ for salary increase and 4 (2.8\%) for other reasons.

\section{DISCUSSION}

The female gender prevailed in the gender characterization; a fact corroborated by the literature on the subject. Other authors describe the predominance of female gender in nursing in the sense that it reproduces an interesting peculiarity of the profession, which was performed in its early days only by women5. Data from a study developed by the Brazilian Federal Council of Nursing (Cofen) in 2015 showed that $84.6 \%$ of nursing professionals in Brazil are female and 15.4\% male ${ }^{6}$. Likewise, this fact is confirmed in several other cultures, in which patient care is pointed out as a continuity of women's occupation. Furthermore, it is believed to be a structural characteristic of health sector services, the superiority of women in activities involving assistance to people $\mathrm{e}^{7-10}$.

Given the majority of females among the professionals in this sample, it was found that this is a prevalent scenario in studies conducted in other locations: among graduates from Nursing course of the State University of Londrina (UEL), $90 \%$ are female; in intensive care units (ICU) in Brazil, 82.5\% are female nurses; among nursing managers of the teaching hospital in Ribeirão Preto, $93.3 \%$ are female; in participants of the improvement course for Obstetric Nursing of the Federal University of Minas Gerais (UFMG), the majority was female $(89 \%)^{8,11-14}$. In a study that outlined the profile of the stomatherapist graduated from the University of Taubaté, it was identified the predominance of female specialists in stomatherapy $(29 / 96.6 \%)^{15}$. These facts corroborate this research data. However, it is important to stress that the growth of male representativeness in nursing and stomatherapy is already evident, according to the results obtained in this study.

Regarding age, most of them were between 31 and 40 years old, data corroborated by studies in which the participants were between 20 and 50 years of age, a period in which the search for a definition or realization of professional development occurs ${ }^{8,16}$. In the study conducted at the University of Taubaté ${ }^{15}$, it was also found a significant value (15/50\%) of graduates aged between 36 to 50 years. In another study, which aimed to discuss and analyze the profile of nurses in an ICU, the mean age was 39.4 years, with a minimum amplitude of 29 years and a maximum of 60 years 10 . These data reinforce a professional profile with a minimum period of experience in the care area or a search for a return to academic activities in a period of greater stability and maturity in their professional career ${ }^{15}$.

Job opportunities in large centers and the ease of access to the Stomatherapy course justify the percentage of $58 \%$ of graduates residing in Belo Horizonte/MG, where the course is offered, and $26 \%$ residing in inland cities in the state of Minas Gerais. In a study carried out with graduates of the University of Taubaté, the majority (23/76.6\%) of the interviewees resided in the Greater São Paulo area ${ }^{15}$.

Of the total number of UFMG graduates, 22 (26.2\%) are residents of inland cities in the state of Minas Gerais. This data is consistent with one of the proposals of the specialization course in Nursing in Stomatherapy of the university under study, which is to produce social impact through the dissemination of scientific knowledge of the specialty to the regions with less representation of specialist professionals and specialized services in the area, providing better care to people who need the assistance of the stomatherapist. This dispersion is by one of the principles of this course, i.e., the concern in proportionally selecting candidates from other regions of Minas Gerais and Brazil, in order 
to disseminate knowledge and specialists throughout the country ${ }^{2,15,16}$.

A study carried out by Martins and collaborators (2006) identified that the completion time of the course might be an indication of the professional's period of experience in the job market and concerning maturity ${ }^{7}$. The undergraduate degree reveals the competencies and skills of the nurse, as well as the time of education at a given time reflects the knowledge and skills valued in a given period ${ }^{17}$. In this study, the number of graduates in the undergraduate course predominated between the years 2006 and 2010, corresponding to 36 (42.8\%) professionals.

Of the 84 participants in this research, 2015 was the predominant year of completion of the Stomatherapy course, when there were 19 (22.7\%) graduates, followed by 2014 when there were $12(14.2 \%)$ graduates. These results may have been influenced by the most recent update of the participants' contact details with the conclusion year next to the survey year.

The specialization in stomatherapy is growing in the domestic market since it has a full possibility of professional activity, in direct patient care, teaching, research, administration, sales, advising, and consulting. The need for newly qualified nursing professionals to work in services is a reality. The nurse and the stomatherapist are liberal professionals and can act in health services of public and private networks, ambulatories, clinics specialized in stomatherapy, home care, and can undertake their business ${ }^{3.18}$.

It should be noted that this study identified that the job market for stomatherapists had absorbed specialists with relative success, considering that, of the 84 participants in the study, 73 (87\%) work as nurses and $59(70 \%)$ in the area of stomatherapy. This result corroborates what has been observed in practice, that the specialization course in Nursing in Stomatherapy has always growing demand. We cannot forget that other factors are attractive for this growing demand, such as the recognition of its quality by professionals of excellence, the participation of renowned stomatherapists in specific disciplines, the formal and legal recognition of the course by Sobest, by the Ministry of Education and Culture (MEC), by UFMG itself and by national and international institutions in the area ${ }^{19}$.
In a study on the sociodemographic profile of nurses in the hospital network, it was found that the high rates of professionals taking specialization courses (65.4\%) are due to the profile of professional desired by the market, with in-depth technical-scientific knowledge within the specific area of work. Nurses who have only the undergraduate course, because they work as generalists, are barely desired by the market and are more exposed to difficulties in their professional activity ${ }^{17}$.

In a study conducted by Paula and Santos ${ }^{20}$, the lack of institutional recognition was pointed out as a negative aspect, because it contributes to the undervaluation of the stomatherapist, due to the lack of interest and understanding of specialized activities, as well as the limited relevance attributed to the performed functions and lack of understanding of effective and assertive outcomes derived from it. Thus, it refers to one more provocation for the stomatherapist: to be able to collaborate for the re-signification of its value and the recognition of the specialty in society. Such statements may be a possible justification for the results of the research, which informs that $13 \%$ of graduates do not work as nurses, and 30\% do not work in the area of specialty. However, the specialty is considered new and growing in the job market.

In a study conducted in the area of obstetrics, it is also possible to notice the difficulty of insertion of specialists in obstetric nursing, because they feel inauthentic and inappropriate about their practical work, without professional identity, with cumulation or deviation from agreed role/position, often excluded from the health team, which generates a state of conformism or frustration. Such difficulties may reflect the negative results of the abandonment of the profession and not working in the specialty ${ }^{8}$.

Regarding the stomatherapy area, the obtained results showed that most graduates work with stomas and wounds; followed by only with wounds; with stomas, wounds and incontinence; with stomas and incontinence; and only with stomas. No participant informed to work specifically and only with incontinence or wounds and incontinence. It is noteworthy in the collected data, the low percentage of stomatherapists who have dedicated themselves to incontinence and, even so, allied to the activity with stomas. Such data reveal a shortage of professionals working in the area 
of incontinence and, consequently, a reduced number of services that cover this area.

The stomatherapist, when professionally linked to a health institution, group cooperatives or as a liberal worker, has legal support to perform care, educational, research, and advisory functions ${ }^{15}$. There is a wide diversity of fields of activity for stomatherapists, which is perceived as growing in the health market in Brazil, where more and more companies arrive with innovative inputs and technologies that need these specialists to test and scientifically evaluate their products, analyze the cost-benefit ratio for patients and institutions, indicate and disclose their productions. Considering also this factor, it is observed that it can foster and instigate the search for specialization in stomatherapy ${ }^{19}$.

Concerning the area of work of the graduates participating in this study, it was noticed that, of the activities related to stomatherapy, the predominant area was care, 59 (29.3\%), followed by self-employed care, 33 (16.4\%), teaching activities, 23 (11.4\%), assistance 19 (9.4\%), consulting 17 (8.5\%), management/ administration and research $13(6.5 \%)$ and sales 11 (5.5\%). There is a predominance of graduates in the care area, which may be related to job opportunities in the labor market, resulting from a need for specialized care and increased valuation of the stomatherapy practice in the care provided by stomatherapists. On the other hand, the practice of self-employed work is growing in nursing, with the support of current legislation, because of the search of nurses for independence from the current competitive labor market, due to the financial crisis in health services ${ }^{21}$.

In a study conducted in Portugal, it was highlighted that the importance of nurses' care, within the scope of the stomatherapy nursing consultation, positively impacts the patients' transition processes, which, due to significant personal changes, require acceptance and adaptation to the new living condition ${ }^{22}$. This context reflects the various opportunities of work of the stomatherapist nurse who performs different functions in the exercise of stomatherapy in preventive, therapeutic, and rehabilitation aspects in search of improving the patients' quality of life ${ }^{3}$.

It was possible to identify through the results of this study that hospitals represent $27.3 \%$ of the area of work of the graduates from the Stomatherapy course at UFMG.
Of these, $27.3 \%, 52 \%$ is equivalent to practice in all sectors, $25 \%$ in the inpatient unit, $17 \%$ in the ambulatory, $6 \%$ in the intensive care unit. These data corroborate a study covering stomatherapy in Brazil from 1990 to 1995, in which 58\% of the respondents also worked in hospital units ${ }^{16}$. Regarding the area of expertise of specialist nurses, another study also showed a predominance (93.60\%) in hospital care ${ }^{8}$.

The percentage of the areas of activity after the hospital area was distributed as follows: $22.2 \%$ in-home care, $13.2 \%$ in ambulatories, $10.5 \%$ in primary healthcare, $7.8 \%$ in industry, $6.8 \%$ in universities/faculties and $4.7 \%$ in private clinics. These data are contrary to the results obtained by Santos ${ }^{16}$, in which the stomatherapists' second-largest area of work was ambulatories, while the present study shows another reality, in which professionals are focused on the home care.

The result of $27.3 \%$ of activity in the hospital area, predominant in this study, was described as growing in a study by Teixeira and collaborators published in $2016^{19}$, which reports that the institution of a stomatherapy service in the hospital area aims to improve and expand the care to inpatients or dehospitalized, with updates in care using efficient therapies and excellence in care, besides reducing costs and the length of hospital stay.

Home care, with a result of $22.2 \%$ of graduates' performance, is probably included in the self-employed form of work of the nurse. According to a study by Kraemer and collaborators ${ }^{21}$, the autonomous nurse can continue his professional practice, aware of his areas of activity, seeking satisfaction for himself and his patients, considering the relevance that his performance represents for people, work processes and health services.

In the professionals' perception, home care is emphasized as an innovative and humanized service modality, an alternative to the hospital-centered health model, also showing its interdisciplinary character ${ }^{22}$.

Andrade and collaborators ${ }^{23}$ showed that the nursing practice in-home space is fundamental and extensive, highlighting relational and educational actions, being necessary even in professional care.

For the development of this autonomy, the job market must reflect the changes that have been happening with nursing practice in the world and enables nurses to exercise their imaginative and resolution capacity ${ }^{21}$.

The reality in the hospital scenario and primary healthcare have ceased to be the main sources of employability 
and keep the professional away from several opportunities in which he experiences greater independence ${ }^{15}$.

Regarding the current or previous jobs of the participants of this research in public or private services, it was verified that $32(38 \%)$ stomatherapists work or have worked in the public service, followed by 24 (29\%) in the private sector and $18(21 \%)$ in both. In a recent study ${ }^{8}$, many graduates of the specialization course in Obstetric Nursing (65.6\%) also worked in public services. Another study corroborates the presented data that the majority (49\%) of nurses in the hospital network have an employment relationship in public institutions ${ }^{17}$. Such data may be a consequence of better structuring of health policies in favor of patients assisted by the public network, which increases opportunities in the public job market for nurses ${ }^{4}$.

According to the results, of the 84 participants, $58(69 \%)$ invested in professional qualification after specialization and 26 (31\%) did not. Among the professionals who continued their qualification, $38(21.4 \%)$ participated in workshops, 31 (17.3\%) in national courses and congresses, $30(16.7 \%)$ in symposia, $23(12.8 \%)$ in scientific meetings, 13 (7.2\%) in international congresses, $9(5 \%)$ graduated from master's degree, $3(1.6 \%)$ did other activities and 1 $(0.6 \%)$ graduated from doctorate. In this question, it was possible to choose more than one answer option.

Another study points out that $25.86 \%$ of graduates of the Obstetric Nursing course attended master's degrees, $3.45 \%$ doctorates and $76.86 \%$ participated in congresses and events in the area of obstetrics ${ }^{8}$, which shows more significant investment in the process of post specialization professional education.

Searching for courses in the specialty area is to look for mastery in practice, moving and combining knowledge, putting values and skills in execution, in order to achieve efficiency in performing tasks required by the nature of the work and in solving problems and unpredictable situations in a cultural scenario ${ }^{8}$. The continuous and indispensable search for technical qualification was also emphasized by stomatherapists, being an essential issue for the preparation of the professional identity of nurses, vigorously, and positively collaborating for the updating and scientific development ${ }^{20}$.

The 31\% of graduates who did not accomplish any postgraduate education may present difficulties of insertion or maintenance in the specific job market since the continuity of the search for knowledge in the area has to be constant ${ }^{20}$.

Among the reasons for attending the specialization in stomatherapy, most graduates answered as the interest in technical-scientific knowledge (48.5\%), followed by the opportunity to develop activities with patient and family (20.7\%), career advancement (18\%), salary increase (10\%) and other reasons (2.8\%). According to Dias and collaborators $^{15}$, postgraduate courses can be considered strategies for the requirements of employability of competent professionals, with independence for decision making to introduce technological advances and be responsible for challenging the adversities of the most different means of production, which corroborates the interest of most graduates of the stomatherapy course at UFMG.

Regarding the limitations of this research, it was possible to notice that there is a scarcity of national publications and lack of international studies on the topic, which hampered the discussion on the presented results. Thus, it is necessary to expand the research on stomatherapist's professional activity.

The results of this study will contribute to the dimensioning and mapping of stomatherapists insertion in the job market and to the possibility of evaluating opportunities for absorption of the specialized practice of the stomatherapist.

\section{CONCLUSION}

This study provided the identification of the area of work, the trajectory in the specialty, and subsequent qualification as a specialist of graduate stomatherapists from the Federal University of Minas Gerais.

Stomatherapist nurses were mostly female, aged between 31 and 40 years, living and working in Belo Horizonte/MG. They remain active in the specialty area, with a predominance of care of stomas and wounds, care activities, in the hospital area and the public health sector. The interest in technical-scientific development mainly motivated the search for specialization, and the graduates remain giving continuity in their qualification after the completion of the specialty.

Stomatherapy is expanding and growing in the national scenario, and further research and interventions 
of the Brazilian Association of Stomatherapy are essential for a more comprehensive view of the specialty and a continuous consolidation of stomatherapy in Brazil.

\section{ACKNOWLEDGMENTS}

We would like to thank all the stomatherapists who participated in the research carried out in this work.

\section{AUTHOR'S CONTRIBUTION}

Conceptualization, Gontijo TG; Borges EL and Ferraz AF; Methodology, Gontijo TG; Borges EL; Ferraz AF and Pires Júnior JF; Investigation, Gontijo TG; Writing - Original Draft, Gontijo TG; Borges EL and Ferraz AF; Writing - Review and Editing, Gontijo TG; Borges EL; Pires Júnior JF and Spira JAO; Supervision, Borges EL.

\section{REFERENCES}

1. Boyle DK. Nursing Specialty Certification and Patient Outcomes: What We Know in Acute Care Hospitals and Future Directions. J Assoc Vasc Access. 2017;22(3):137-42. https://doi.org/10.1016/j.java.2017.06.002

2. Yamada BF, Ferrola EC, Azevedo GR, Blanes L, Rogenski NM, Santos VL. Competências do Enfermeiro Estomaterapeuta (ET) ou do Enfermeiro Pós-graduado em Estomaterapia (PGET). ESTIMA, Braz J Enterostomal Ther. 2008;6(1):33-43.

3. SteltonS. The WCET at40. Adv Skin Wound Care. 2018;31(4):15051. https://doi.org/10.1097/01.ASW.0000531296.56431.c1

4. Santos VLCG. Cuidando do estomizado: análise da trajetória no ensino, pesquisa e extensão. São Paulo. Tese (LivreDocência) - Escola de Enfermagem da Universidade de São Paulo; 2006.

5. Viana RAPP, Vargas MAO, Carmagnani MIS, Tanaka LH, Luz KR, SchmittPH. Perfil do enfermeiro de terapia intensiva em diferentes regiões do Brasil. Texto Contexto Enferm. 2014;23(1):151-59. https://doi.org/10.1590/S0104-07072014000100018

6. Conselho Federal de Enfermagem (Cofen). Pesquisa inédita traça perfil da enfermagem [internet]. [Citado 18 dez 2018]. Disponível em: http://www.cofen.gov.br/pesquisa-ineditatraca-perfil-da-enfermagem_31258.html

7. Martins C, Kobayashi RM, Ayoub AC, Leite MMJ. Perfil do enfermeiro e necessidades de desenvolvimento de competência profissional. Texto Contexto Enferm. 2006;15(3):472-78. https:// doi.org/10.1590/S0104-07072006000300012

8. Carlos GAV, Matozinhos FP, Carmo JMA, Manzo BF, Duarte ED, Souza KV. Perfil dos participantes de um curso de aprimoramento em Enfermagem obstétrica. REME - Rev Min Enferm. 2019;23:e-1153. https://doi.org/10.5935/14152762.20190006

9. Nicácio MC, Heringer ALS, Schroeter MS, Pereira ALF. A prática profissional das enfermeiras obstétricas na casa de parto e hospital: um estudo descritivo. Online Braz J Nurs. 2016;15(2):205-14. https://doi.org/10.17665/16764285.20165203
10. Oliveira PVN, Matias AO, Valente GSC, Messias CM, Rosa FSMS, Souza JDF. Formação do enfermeiro para os cuidados de pacientes críticos na Unidade de Terapia Intensiva. Nurs. 22(250):2751-2755.

11. Camelo SHH, Soares MI, Chaves LDP, Rocha FLR, Silva VLS. Nurse managers atateaching hospital:training, responsibilities and challenges. Rev Enferm UERJ. 2016;24(3):1-6. https://doi. org/10.12957/reuerj.2016.11637

12. Souza SNDH, Miyadahira AMZ. O desenvolvimento de competências no Curso de Graduação em Enfermagem de egressos. Cienc Cuid Saúde. 2012;1:243-50. https://doi. org/10.4025/cienccuidsaude.v11i5.17082

13. Cavalcante EFO, Silva DMGV. Nurses' commitment to the care of tuberculosis patients. Texto Contexto Enferm. 2016;25(3):110. https://doi.org/10.1590/0104-07072016003930015

14. Lazarini FM, Barbosa DA. Educational intervention in Primary Care for the prevention of congenital syphilis. Rev Latino-Am Enfermagem. 2017;25:1-9. https://doi.org/10.1590/15188345.1612.2845

15. Dias MSC, Boccara de Paula MA, Morita ABPS. Perfil Profissional de Enfermeiros Estomaterapeutas Egressos da Universidade de Taubaté. ESTIMA, Braz J Enterostomal Ther. 2014;12(3).

16. Santos VLCG. Ensino especializado de estomaterapia no Brasil:1990-1995. Rev Latino-Am Enfermagem. 1998;6(3):4354. https://doi.org/10.1590/S0104-11691998000300006

17. Araujo MAN, Lunardi Filho WD, Alvarenga MRM, Oliveira RD, Souza JC, Vidmantas S. Perfil sociodemográfico dos enfermeiros da rede hospitalar. Rev Enferm UFPE. 2017;11(11):4716-725.

18. Fernandes JD, Silva RMO, Mota LSR, Silva ACP, Silva LS, Freitas CM. Mapeamento dos Cursos de Especialização em enfermagem em sua totalidade e contradições. Rev Enferm UFPE. 2017;11(6):2459-465.

19. Teixeira AS, Menezes LC, Oliveira RM. Serviço de Estomaterapia na perspectiva dos gerentes de enfermagem 
em Hospital Público de Referência. ESTIMA, Braz J Enterostomal Ther. 2016;14(1).

20. Paula MAB, Santos VLCG. O significado de ser especialista para o enfermeiro estomaterapeuta. Rev Latino-Am Enfermagem. 2003;11(4):474-82. https://doi.org/10.1590/ S0104-11692003000400010

21. Kraemer FZ, Duarte MLC, Kaiser DE. Autonomia e trabalho do enfermeiro. Rev Gaúcha Enferm. 2011;32(3):487-97. https://doi.org/10.1590/S1983-14472011000300008
22. Miranda LSG, Carvalho AAS, Paz EPA. Qualidade de vida da pessoa estomizada: relação com os cuidados prestados na consulta de enfermagem de estomaterapia. Esc Anna Nery. 2018;22(4):487-94. https://doi.org/10.1590/2177-9465ean-2018-0075

23. Andrade $A M$, Silva $K L$, Seixas $C T$, Braga PP. Atuação do enfermeiro na atenção domiciliar: uma revisão integrativa da literatura. Rev Bras Enferm. 2017;70(1):210-19. https:// doi.org/10.1590/0034-7167-2016-0214 